\title{
In vitro and in vivo Effects of Riboflavin Sodium Phosphate on the Phagocytic Activity of Peritoneal Macrophages in Mice
}

\author{
Makoto KIMURA, Mamoru SUZUKI* \\ and Seiichi ARAKI* \\ Animal Health Product Division, Eisai Co., Ltd., Bunkyo-ku, \\ Tokyo 112 \\ * Research and Development Division, Eisai Co., Ltd., \\ Tsukuba-shi 300-26
}

(Received December 19, 1995)

\begin{abstract}
The in vitro and in vivo effects of riboflavin sodium phosphate (vitamin $\mathrm{B}_{2}$ sodium phosphate: $\mathrm{VB}_{2} \mathrm{Na}$ ) on host defense mechanisms, especially macrophage function, were investigated in mice. $\mathrm{VB}_{2} \mathrm{Na}(100 \mathrm{mg} / \mathrm{kg})$ was injected intraperitoneally or intravenously at 1 day before the phagocytosis assay. After intraperitoneal administration, the phagocytic index of peritoneal macrophages in the control and $\mathrm{VB}_{2} \mathrm{Na}$-treated groups was $8.3 \pm 1.6 \%$ and $34.6 \pm 6.8 \%$, respectively, with the index being about 4 -fold higher in the treated mice $(\mathrm{p}<0.01)$. After intravenous administration, the phagocytic index of peritoneal macrophages was $6.6 \pm 2.1 \%$ and $15.4 \pm 3.7 \%$ in control and $\mathrm{VB}_{2} \mathrm{Na}$-treated mice, respectively, and the treated mice again showed a significantly higher index $(p<0.01)$. Intravenous administration of $\mathrm{VB}_{2} \mathrm{Na}$ showed as effective as intraperitoneal administration. In a separate investigation of the direct effect of $\mathrm{VB}_{2} \mathrm{Na}$ on macrophage activity, we determined the in vitro phagocytic index of mouse peritoneal macrophages for latex particles in the presence of various concentrations of $\mathrm{VB}_{2} \mathrm{Na}$. Addition of $\mathrm{VB}_{2} \mathrm{Na}$ at a concentration of more than $25 \mu \mathrm{g} / \mathrm{m} l$ increased the phagocytic index. Thus, our results suggest that $\mathrm{VB}_{2} \mathrm{Na}$ enhances macrophage function both in vitro and in vivo.
\end{abstract}

Anim. Sci. Technol. (Jpn.) 67 (4) : 368-373, 1996

Key words : Immunopotentiator, Mouse, Peritoneal macrophage, Phagocytic activity, Riboflavin sodium phosphate $\left(\mathrm{VB}_{2} \mathrm{Na}\right)$

It is generally accepted that the development of disease in domestic food animals, such as respiratory disease in cattle and pigs, involves the interaction of host exposure to stress combined with viral or bacterial challenge. Indeed, several studies have shown that stressand pathogen-induced immunosuppression contributes to the development of bovine respiratory disease ${ }^{7)}$. If such immunosuppression in livestock is related to abnormal immune regulation, then methods of modulat- ing the immune response should be of benefit. Enhancing both specific and nonspecific defense mechanisms against infection is of interest to veterinarians. Many biological response modifiers (e.g., physiological products, microbial substances, and synthetic compounds) have been tested for use as immunopotentiators or immunomodulators in domestic food animals ${ }^{7,9,14}$. So far, immunomodulators appear to have the greatest potential for the prevention and/or treatment of 
early infections associated with immunosuppression $^{97}$. With the aim of applying immunologically active substances to the treatment of domestic food animals, we have previously explored the possibility of administering dihydroheptapreno $]^{1,2,8,11,15,19-21)}$ or fermented egg white powder ${ }^{3,4,12,13,16)}$, and both substances were shown to enhance neutrophil and macrophage function.

Riboflavin (vitamin $\mathrm{B}_{2}: \mathrm{VB}_{2}$ ) has been found to enhance nonspecific host defense mechanisms against a variety of bacterial infections in mice by stimulating the generation of neutrophils and by enhancing macrophage function ${ }^{5)}$. In addition, $\mathrm{VB}_{2}$ has been reported to stimulate neutrophil function in calves and cows $^{(7)}$.

In the present study, to elucidate the mechanism of action of riboflavin sodium phosphate (vitamin $\mathrm{B}_{2}$ sodium phosphate: $\mathrm{VB}_{2} \mathrm{Na}$ ), we investigated its in vitro effect on the phagocytic activity of mouse peritoneal macrophages, and also performed an in vivo investigation in mice to determine whether intraperitoneal or intravenous administration could modulate peritoneal macrophage activity.

\section{Materials and Methods}

Animals: Outbred male mice (slc: ICR) were obtained from Japan SLC, Inc, and were used for these studies at 5-6 weeks of age when they weighed $28-32 \mathrm{~g}$. The mice were maintained at $22 \pm 2{ }^{\circ} \mathrm{C}$ with a 12 -h light-dark cycle, and were given standard laboratory chow (Oriental Yeast Co., Tokyo, Japan) and water ad libitum.

Preparation of $\mathrm{VB}_{2} \mathrm{Na}$ : $\mathrm{VB}_{2} \mathrm{Na}$ (Wako-Pure Chemical Co., Tokyo, Japan) was prepared as a $0.5 \% \mathrm{w} / \mathrm{v}$ solution in sterile water for injection (Otsuka Pharmaceutical Co., Tokushima Japan), and then passed through a $0.22-\mu \mathrm{m}$ membrane filter (Millipore Bedford, MA, U.S.A.) before use. Endotoxin was not detected in this preparation by the Limulus amoebocyte lysate assay (Limulus $\mathrm{J}$ Single Test Wako,
Wako-Pure Chemical Co., Tokyo, Japan).

Preparation of peritoneal macrophages: Mice were killed by exsanguination via the carotid artery under ether anesthesia and peritoneal macrophages were harvested after the intraperitoneal injection of $5 \mathrm{~m} l$ of cold Hanks' balanced salt solution (HBSS ; Gibco Laboratories, U.S.A.). The cell suspension obtained from the peritoneal cavity was washed twice with cold HBSS by centrifugation for $10 \mathrm{~min}$ at $1,000 \mathrm{rpm}$, and the resultant cells consisted exclusively of macrophages. These cells were then suspended at $1 \times 10^{6} / 0.5 \mathrm{~m} l$ in Eagle's minimal essential medium (Nissui, Pharmaceutical Co., Tokyo, Japan) containing $15 \%$ inactivated murine serum.

In vivo study: Groups of 5 mice received an intraperitoneal or intravenous injection of $\mathrm{VB}_{2} \mathrm{Na}$ at a dose of $100 \mathrm{mg} / \mathrm{kg}$. Control mice were given the same volume of vehicle (sterile water for injection) alone. The phagocy tic activity of peritoneal macrophages was determined at 1 day after injection.

In vitro study: Macrophages were harvested from 10 untreated mice and pooled. Then the macrophages $\left(1 \times 10^{6}\right.$ cells in $0.5 \mathrm{~m} l$ of Eagle's minimal essential medium with $15 \%$ inactivated murine serum) were treated with various concentrations of $\mathrm{VB}_{2} \mathrm{Na}$ or $100 \mu \mathrm{g} / \mathrm{ml}$ muramyldipeptide (MDP; a reference drug), and were incubated for $24 \mathrm{~h}$ at $37^{\circ} \mathrm{C}$ in slide chambers (four-compartment type; Lab-Tek Products, Inc., Naperville, Ill., U.S.A.) with 5\% $\mathrm{CO}_{2}$. Phagocytic activity was determined at the end of this period incubation.

Phagocytic activity assay : Fluorescent monodispersed carboxylated microspheres (Polyscience, Inc., Warrington. PA) were suspended $\left(1 \times 10^{7} / 0.05 \mathrm{ml}\right)$ in $1 \mathrm{~m} l$ of $15 \%$ inactivated murine serum in Eagle's minimal essential medium and added to a macrophage suspension $\left(1 \times 10^{6}\right.$ cells in $0.5 \mathrm{~m} l$ of Eagle's minimal essential medium with $15 \%$ inactivated murine serum). Then the cells were incubated for $1 \mathrm{~h}$ at $37^{\circ} \mathrm{C}$ in a slide chamber with $5 \% \mathrm{CO}_{2}$. The 
slide chamber was washed 5 times with warm HBSS, and adherent cells were stained with Giemsa solution for observation under a microscope. The phagocytic index was calculated as follows : phagocytic index $(\%)=$ (number of cells incorporating 8 or more latex particles/ 200 cells) $\times 100$.

Statistical analysis: Results were analysed statistically using Student's $t$-test.

\section{Results and Discussion}

We previously reported that a lecithin $\mathrm{VB}_{2}$ emulsion increased host resistance to bacterial infection $^{5)}$. Therefore, the effect of water-soluble $\mathrm{VB}_{2} \mathrm{Na}$ on host defense mechanisms, especially macrophage function, was investigated in the present study.

The phagocytic index of peritoneal macrophages in the control and $\mathrm{VB}_{2} \mathrm{Na}$-treated groups was $8.3 \pm 1.6 \%$ and $34.6 \pm 6.8 \%$, respectively, after intraperitoneal administration, and the phagocytic index was about 4-fold higher in the treated mice $(p<0.01)$ (Fig. 1).

The phagocytic index of peritoneal macrophages was $6.6 \pm 2.1 \%$ and $15.4 \pm 3.7 \%$ in the

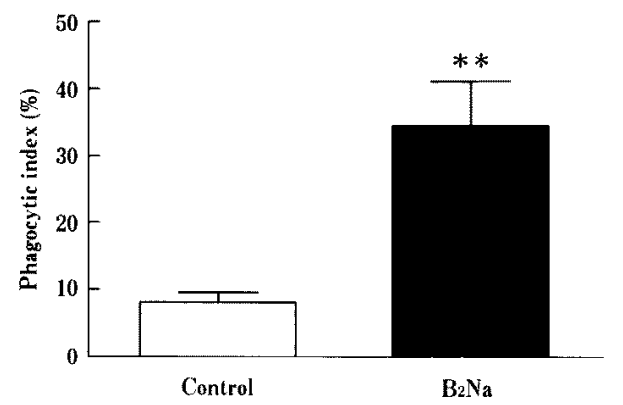

Fig. 1. In vivo effect of intraperitoneal (i.p.) injection of $\mathrm{VB}_{2} \mathrm{Na}$ on the phagocytosis of latex particles by mouse peritoneal macrophages.

Groups of 5 mice were injected with $\mathrm{VB}_{2} \mathrm{Na}(100$ $\mathrm{mg} / \mathrm{kg}$, i.p.).

Results are expressed as the mean and standard deviation.

** $: \mathrm{p}<0.01$ (Student's $t$-test).

$\mathrm{VB}_{2} \mathrm{Na}$ : Vitamin $\mathrm{B}_{2}$ sodium phosphate.

Control : Vehicle only. control and $\mathrm{VB}_{2} \mathrm{Na}$-treated mice, respectively, after intravenous injection, and the treated mice again showed a significantly higher phagocy tic index $(\mathrm{p}<0.01)$ (Fig. 2).

In a separate experiment performed to evaluate the direct effect of $\mathrm{VB}_{2} \mathrm{Na}$ on macropage activity, we determined the in vitro phagocytic activity of mouse peritoneal macrophages for latex particles in the presence of various concentrations of $\mathrm{VB}_{2} \mathrm{Na}$. Addition of $\mathrm{VB}_{2} \mathrm{Na}$ at concentrations of more than $25 \mu \mathrm{g} / \mathrm{ml}$ enhanced phagocytic activity (Fig. 3).

These results suggested that $\mathrm{VB}_{2} \mathrm{Na}$ could enhance macrophage function both in vitro and in vivo.

We have previously reported that intramuscular injection of $\mathrm{VB}_{2}$ at doses of 12.5$100 \mathrm{mg} / \mathrm{kg}$ enhanced host defences against experimental Escherichia coli infection in mice. $\mathrm{VB}_{2}$ also exhibited a protective effect against Pseudomonas aeruginosa, Klebsiella pneumoniae, Staphylococcus aureus, and Actinobacillus pleuropneumoniae. The mechanism by which $\mathrm{VB}_{2}$ en hances resistance in mice may be related to the stimulation of neutrophil and monocyte

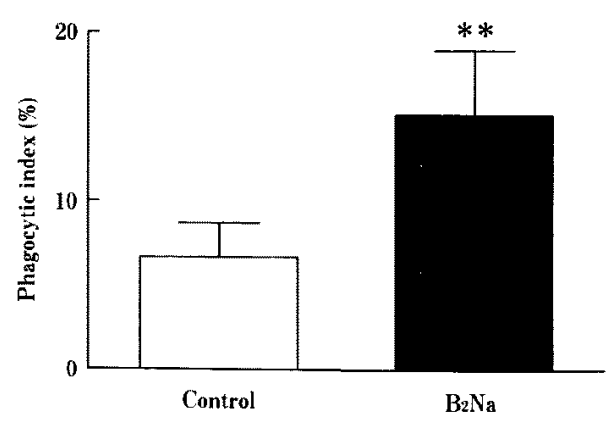

Fig. 2. In vivo effect of intravenous (i.v.) injection of $\mathrm{VB}_{2} \mathrm{Na}$ on the phagocytosis of latex particles by mouse peritoneal macrophages.

Groups of 5 mice were injected with $\mathrm{VB}_{2} \mathrm{Na}(100$ $\mathrm{mg} / \mathrm{kg}$, i.v.).

Results are expressed as the mean and standard deviation.

** $: \mathrm{p}<0.01$ (Student's $t$-test).

$\mathrm{VB}_{2} \mathrm{Na}$ : Vitamin $\mathrm{B}_{2}$ sodium phosphate.

Control : Vehicle only. 


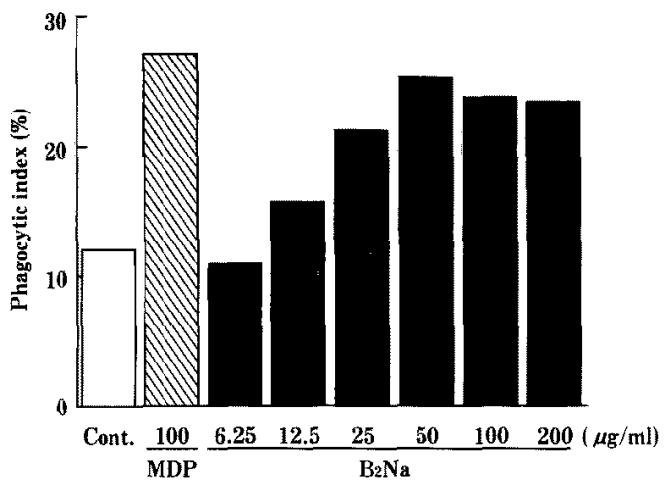

Fig. 3. In vitro effect of $\mathrm{VB}_{2} \mathrm{Na}$ on the phagocytosis of latex particles by mouse peritoneal macrophages.

$\mathrm{VB}_{2} \mathrm{Na}$ : Vitamin $\mathrm{B}_{2}$ sodium phosphate.

MDP : Muramyldipeptide

Control : Vehicle only.

proliferation as well as to the activation of macrophages ${ }^{5)}$.

Osame et $a l .{ }^{17)}$ reported the marked enhancement of nitroblue tetrazolium reduction and phagocytic killing by peripheral neutrophils obtained from calves and cows at 1-6 days after the intramuscular injection of $\mathrm{VB}_{2}(5-20 \mathrm{mg}$ / $\mathrm{kg}$ ).

The present study demonstrated that intraperitoneal or intravenous injection of water -soluble $\mathrm{VB}_{2} \mathrm{Na}$ was also able to activate macrophages. In addition, $\mathrm{VB}_{2} \mathrm{Na}$ directly activated macrophages in vitro. However, it remains unclear whether the in vivo effects of $\mathrm{VB}_{2}$ or $\mathrm{VB}_{2} \mathrm{Na}$ are due to a direct action on neutrophils or an indirect action via the stimulation of macrophages or other cells to produce soluble mediators, such as colony stimulating factors, inteferons, and interleukins.

A major function of neutrophils and macrophages is the phagocytosis, digestion, and destruction of invading microorganisms, and a congenital or acquired defect of phagocytic activity will result in enhanced susceptibility to bacterial pathogens ${ }^{6)}$. Therefore, phagocytes play a pivotal role in protecting the host against microbial infection ${ }^{18)}$. Thus, our findings suggest that $\mathrm{VB}_{2} \mathrm{Na}$ might be useful as a nonspecific immunopotentiator for preventing opportunistic infection in domestic animals. Further investigation of the effect of $\mathrm{VB}_{2} \mathrm{Na}$ on host defence mechanisms is currently in progress at our laboratories.

\section{References}

1) Araki $S$, Kagaya K, Kitoh $K$, Kimura $M$, Fukazawa $Y$. Enhancement of resistance to Escherichia coli infection in mice by dihydroheptaprenol, a synthetic polyprenol derivative. Infect. Immun., 55 : 2164-2170. 1987.

2) Araki S, Suzuki M, Ogura K, Kimura M, Imamura E, Kuniyasu C, Kagaya K, Fukazawa Y. Enhancement of phagocytosis and bactericidal activity of neutrophils in miniature pigs by dihydroheptaprenol, a synthetic polyprenol derivative. Microbiol. Immunol, $33: 877-882.1989$.

3) Araki S, Suzuki M, Fujimoto M. Enhanced resistance to bacterial infections in mice by oral administration of an active egg white product. J. Vet. Med. Sci., 54 : 1055-1056. 1992.

4) Araki S, Kimura M, Suzuki M, Fujimoto M. Effect of active egg white product on neutrophil function in weanling piglets. J. Vet. Med. Sci., 55 : 899-900. 1993.

5) Araki S, Suzuki M, Fujimoto M, Kimura $M$. Enhancement of resistance to bacterial infection in mice by vitamin $B_{2}$. J. Vet. Med. Sci., 57 : 599-602. 1995.

6) Baehner RL. Disorders of leukocy tes leading to recurrent infection. Ped. Clin. North Am., 19 : 935-956. 1972.

7) Blecha F. Immunomodulation : A means of disease prevention in stressed livestock. J. Anim. Sci., 66 : 2084-2090. 1988.

8) Fukazawa $Y$, Kagaya $K$, Yamada T, Araki S, Kimura M, Sugihara Y, Kitoh K. Enhancement of resistance to experimental candidiasis and cryptococcosis in mice by dihydroheptaprenol, a synthetic polyprenol derivative. In : Recent Progress in Antifungal Chemotherapy. (Yamaguchi H, Kobayashi GS, Takahashi $\mathrm{H}$ eds.) 283-292. Marcel Dekker, Inc. New York. 1991.

9) Kehrli ME JR, Roth JA. Chemically induced immunomodulation in domestic food animals. Adv. Vet. Sci. Comp. Med., 35 : 103 -119. 1990.

10) Kelley KW. Stress and immune function: A 


\section{KIMURA, SUZUKI and ARAKI}

bibliographic review. Ann. Rech. Vet, $11: 445$ 478. 1980.

11) Kimura M, Araki S, Nakai T, Kume K. Protective effect of dihydroheptaprenol in combination with vaccine to experimental Actinobacillus pleuropneumoniae infection in guinea pigs and pigs. J. Vet. Med. Sci., 55 ; $627-$ 630. 1993.

12) Kimura M, Araki S, Suzuki M, Fujimoto $M$. Effect of oral administration of fermented egg white powder on peritoneal and alveolar macrophage function in mice. Anim. Sci. Technol. (Jpn.), 65 : 49-52. 1994.

13) Kimura M, Suzuki M, Araki S. Effect of oral administration of fermented egg white powder on experimental Escherichia coli infection in immunosuppressant-treated mice. Anim. Sci. Technol. (Jpn.), $66: 770-772.1995$.

14) Mulcahy G, Quinn PJ. A review of immunomodulators and their application in veterinary medicine. J. Vet. Pharmacol. Therap., $9: 119-139.1986$.

15) Nagahata $H$, Kociba GJ, Noda $H$, Koiwa $M$, Kimura M. Effects of dihydroheptaprenol on the neutrophil function of postpartum dairy cows. Vet. Immunol. Immunopathol, 29 : 163169. 1991.

16) Nakagawa J, Osame S, Ichijo S, Araki S,
Kimura M. Effects of active egg white product on neutrophil function in calves. J. Vet. Med. Sci., $55: 259-263.1993$.

17) Osame $S$, Araki $S$, Kimura M. Effects of vitamin $B_{2}$ on neutrophil functions in cattle. J. Vet. Med. Sci., $57: 493-495.1995$.

18) Takeya $K$, Mituyama $M$. The relative contribution of phagocytic cells to defense against several kinds of bacterial infection. In : Self-defense Mechanisms. (Mizuno D, Cohn ZA, Takeya K, Ishida $\mathrm{N}$ eds.) 253-263. Univ. Tokyo Press, Tokyo and Elsevier Biomedical Press. Amsterdam. 1982.

19) Watari $T$, Goitsuka $R$, Koyama H, Sako $T$, Uchino T, Araki S, Hasegawa A, Motoyoshi S. Effect of dihydroheptaprenol on nitroblue tetrazolium reduction by swine alveolar macrophages. Jpn. J. Vet. Sci., $51: 630-631$. 1989.

20) Yoneyama O, Osame S, Ichijo S, Kimura M, Araki S, Suzuki M, Imamura E. Effects of dihydroheptaprenol on neutrophil functions in calves. Br. Vet. J., $145: 531-537.1989$.

21) Yoneyama O, Osame S, Kimura M, Araki S, Ichijo S. Enhancement of neutrophil function by dihydroheptaprenol in adult cows. Jpn. J. vet. Sci., 51 : 1283-1286. 1989. 
マウスの腹腔マクロファージの食食能に及ぼすリン酸リボフラビン ナトリウムの in vitro および in vivo での影響

\author{
木村 誠・鈴木 護* ·荒木誠一* \\ エーザイ(株)アニメイト事業部開発室，東京都文京区 112 \\ *エーザイ(株)筑波研究所動物研究室, つくば市 300-26
}

マウスの腹腔マクロファージ $(\mathrm{M} \phi)$ の宔食能に及ぼすリン酸りボフラビンナトリウム $\left(\mathrm{VB}_{2} \mathrm{Na}\right)$ の影 響を検討した. in vivo 試験では，1群 5 匹のマウス（ICR，ð，5週齢）に $\mathrm{VB}_{2} \mathrm{Na}$ を注射用蒸留水で溶 解し， $100 \mathrm{mg} / \mathrm{kg}$ を腹腔又は静脈内に投与した。投与後 1 日目に腹腔内から $\mathrm{M} \phi$ を採取し，M テックス粒子をラブテックチャンバー内で $37^{\circ} \mathrm{C}, 5 \% \mathrm{CO}_{2}$ の条件下で 24 時間培養し, 貪食試験を実施 した。 in vitro 試験は, 腹㓐内より常在 $\mathrm{M} \phi$ を採取し， $\mathrm{M} \phi$ と各種濃度の $\mathrm{VB}_{2} \mathrm{Na}$ (最終濃度 $200 \mu \mathrm{g} / \mathrm{m} l$ ) 又はムラミルジペブキド（MDP，鼠終濃度 $100 \mu \mathrm{g} / \mathrm{ml}$ ) をラブテックチャンバー内で $37^{\circ} \mathrm{C}, 5 \% \mathrm{CO}_{2}$ の 条件下で 24 時間培盖し, その後, ラテックス粒子を添加して領食試験を実施した、VB $\mathrm{V}_{2} \mathrm{Na}$ 腹热内投与 群のラテックス粒子に対する $\mathrm{M} \phi$ の頜食率は, $34.6 \pm 6.3 \%$ でり, 対照群の $8.3 \pm 6.3 \%$ と比較して約 4 倍の上昇を示し，その差は統計学的にも有意であった（p<0.01）。 また， $\mathrm{VB}_{2} \mathrm{Na} の$ 静脈内投与群の貪食 率は $15.4 \pm 3.7 \%$ であり, 対照群の $6.6 \pm 2.1 \%$ と比較して統計学的にも有意な上昇を示した（p<0.01）.

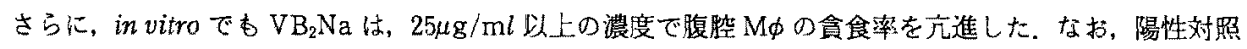
に用いた MDP む $\mathrm{M} \phi$ の食食率を芹進した。. 以上の結果から， $\mathrm{VB}_{2} \mathrm{Na}$ は in vitroおょび in vivoにおい て $\mathrm{M} \phi$ の機能を直接的に增強することが示唆された。

日畜会報， 67 (4) : 368-373, 1996 